\title{
OPLYSNING, OPLEVELSE OG ARBEJDE I ET EU-MAL 3-OMRÅDE OM PROJEKT HEJREDE VOLD
}

Karen Lokkegaard Poulsen

Et godt udgangspunkt for dybtgående studier indenfor museumshistorie/museologi er at focusere vekselvirkningen imellem samfundet - dets tilstand, struktur, udviklingstrin og holde det op imod den fremtraden, form og aktivitet, som kendetegner museumsvirksombeden. Det er meget naturligt, at museer er centrale institutioner $i$ samfundsudvikling og ofte har stor politisk betydning, fordi karnen i museumsarbejde er funktionen som publikums kollektive hukommelse gennem indsamling, forskning og bevaring, og som skatkammer for genstande, der betyder noget for menneskers identitetsfolelse.

Forholdet er ret afdampet i Skandinavien. I Tyskland, hvor udviklingen på museumsomrädet efter 1. Verdenskrig er skrammende pà grund af den styrke, hvormed museerne engagerede sig politisk, er der efter "die Wende» $i$ 1989, foregàet en nuanceret selvransagelse. Den har taget udgangspunkt netop i dynamikken mellem samfund og museum og belyser bl.a. den politiske rolle, museer og de historiske og beslagtede fag, herunder sprogvidenskab, pätog sig ved at producere materiale til den propaganda, som Det 3. Riges nazister havde brug for. Efter 2. Verdenskrig i DDR arbejdede museer og de samme fag med et tilsvarende arbejde for at legitimere endnu et politisk system, nu kommunismen.'

Når museerne i Danmark i 1900-tallet formulerede budskaber med et politisk indhold, fremtrådte de ret underforstået. I første halvdel af 1800-tallet er der derimod lighed i den udvikling, de to lande, Danmark og Tyskland fulgte, og i måden, den tidlige historie og forhistorien blev brugt af kunstnere og videnskabsfolk som samlingsmærke for nationens befolkning. I tiden op til Grundloven legitimerede den danske arkæolog J.J.A. Worsaae således det unge fag, arkæologi, ved at det var et hensigtsmæssigt redskab til at skabe national identitet. I Danmarks Oldtid 
110 oplyst ved Oldsager og Gravhöie, er afsnittet "Oldtidsmindernes betydning for Nationaliteten" en regulær programerklæring for "Urhistoriens" værdi som samlingsmærke og central myte for danskernes opfattelse af sig selv som et folk:

Vi see vore Fædre førstegang trænge ind i Landet og med skarpe Vaaben underkue de derboende udannede Folk; vi see dem udbrede Kundskab om Metaller, Agerdyrkning og i det Hele en høiere Cultur. I vore hænder have vi deres Sværd, hvormed de gjorde det danske Navn anseet og frygtet; ja vi kunne endog fremvise det Bytte af Smykker og Kostbarheder, som de hjembragte fra deres Færd i fremmede Lande. Det er saaledes, at Levningerne fra Fortiden binde os fastere til vort Fædreland. Bakker og Dale, Marker og Enge træde $i$ en mere levende Forbindelse med os; thi giennem Gravhøiene, som kneise paa deres Overflade, og giennem Oldsagerne, som de i Aarhundreder have bevaret i deres Skjød, tilbagekalde de stadig i Erindringen, at vore Fædre, som et eget, uafhængigt Folk, fra umindelige Tider af have boet her $\mathrm{i}$ Landet, og de opfordre os herved kraftigen til at værne om vore Enemærker, at ikke Fremmede skulle raade over en Jordbund, som giemmer vore Fædres Been og hvortil vore helligste og ærværdigste Minder ere knyttede. Den Opmærksomhed, som allerede nu vises Oldtidens Mindesmærker, er derfor visselig ikke uden dybere Grund. Den er et Tegn paa, at det danske Folk $\mathrm{i}$ sin forestaaende høiere Udvikling ikke blindthen vil slutre sig til andre Lande, men at det snarere, ved at vende Blikket indad mod sig selv, vil føie Oldridens Kraft til Nutidens K'logt og saaledes uddanne sig selvstændigt og frit.

Omend faget arkæologi i Danmark i sit faglige indhold og analysemetoder har arbejdet tæt op ad den tyske tradition, har der lykkeligvis været en klar forskel i 1900-tallets politiske brug af faget. I modsærning til Tyskland har de danske museer - når et politisk budskab var til stede, præsenteret dette mere underforstået, undertiden som en holdningstilkendegivelse til publikums egen stillingtagen. Statsmagten og anden øvrighed har ikke markeret sig så massivt $\mathrm{i}$ forhold til museerne, at disse institutioners formidling fik den karakter som den havde i Tyskland, at retfærdiggøre en politisk ideologi ved at sætte den ind $\mathrm{i}$ en historisk sammenhæng og begrunde og fremstille den som en lovmæssighed i menneskehedens udvikling. Alligevel er der også i Danmark en sammenhæng mellem en aktuel politisk og samfundsmæssig situation og museumsudstilling eller den undervisning, der leveres i folkeskolen i fager historie. Blor der forhold, at faget historie i den danske folkeskole er det, hvortil der er udarbejdet flest læseplaner, taler sit tydelige sprog. Faget er holdningsdannende, og en ny undervisningsminister oplever derfor ofte, at gældende læseplaner er ude af trit med samfundsudviklingen og derfor har behov for revision.

\section{DUALISMEN, SAMFUND - MUSEUM I DAGENS DANMARK}

I det moderne danske museumslandskab fylder netværket af lokalmuseer meget. Nye arbejdsformer, en ny museumsfaglighed, nye relationer til museumspublikum og nye formidlingsmetoder blev skabt ved den decentralisering af museumsvæsnet, som for alvor tog fart i $1970^{\circ}$ erne med udlægning af lovbundne opgaver og andre funktioner, som hidril var varetaget centralt. Institutionerne er præget af nærheden til lokalsamfundet og forbinder på én 
gang mikrokosmos og detaljen med det nationale museumsvæsens arbejdsområder og det internationale. Samtidig med tilpasningen til lokalsamfundet er der $\mathrm{i}$ en del amter sket en specialisering på det enkelte museum, og regulære specialmuseer er kommet til. Dette er en naturlig udvikling i et så fintmasket netværk, hvor det enkelte museums kapaciter og faglighed alligevel skal kunne udfolde sig bedst muligt. Med den udvikling, der i øjeblikket foregår på museumsområdet, tegner det til, at denne tendens vil forstærkes, og museerne i de kommende år vil specialisere sig yderligere, hvorved den profil, det enkelte museum har, bliver mere unik.

\section{Lolland - en analyse af landsdelens egenart}

I den årrække, jeg som museumsinspektør har haft ansvaret for arkæologisk arbejde $\mathrm{i}$ Lolland-Falsters Stiftsmuseums virkeområde, er kursen for arbejdet afstukket ved en analyse af det dynamiske felt mellem samfundets behov/situation og de faglige hensyn, d.v.s. med det samme redskab, som er hensigtsmæssigt at bruge ved museumshistoriske studier. Hvor man ved museumshistorie skuer bagud i tid, er arbejdsplanlægningens tidsperspektiv nutid, kombineret med en vision om fremtid. Følgende samfundsmæssige forhold har jeg givet høj prioritet i planlægningen:

- Områdets placering i Østersøregionen, ikke mindst med den ny geografi efter 1989. At formidle fortiden, så museumsgæsten kunne fă et redskab i hænde til at se hen over efterkrigstidens 50 år med de barrierer for gensidig kontakt og kulturudveksling, som prægede området. Det er bl.a. foregåer ved flere vandreudstillinger, der formidlede sam- menhænge på tværs af det tidligere jerntæppe, og hvis budskab jeg satte i relief, ved at udbygge dem med afsnit med genstande fra museets egen samling. Udstillingerne har været båret af museets og museumsgæsternes nysgerrighed over, hvad der mon findes i de hidtil så lukkede egne og af glæden over at se det.

- Det forhold, at anlægsvirksomheden i Stiftsmuseets virkeområde er lav $\mathrm{i}$ forhold til andre dele af Danmark. En lav takt i offentligt anlægsarbejde er hæmmende for arbejdsmulighederne på et arkæologisk arbejdende lokalmuseum, da disse museer i Danmark i stor stil baserer feltarbejdet på det lovbundne arbejde og den eksterne økonomi, der følger med undersøgelse af de levn, som er truet af anlægsarbejde o.l. Der er en tendens til, at de museer, der indenfor det arkæologiske fagområde har groet sig store, ligger i regioner med en anseelig aktivitet indenfor den offentlige anlægssektor.

- Den store arbejdsløshed. Heri ligner området andre randområder i Østersøegnene. F. eks. har skibsværfterne haft svært ved at klare sig, hvad enten det er $\mathrm{i}$ Kiel, Rostock eller Nakskov. Arbejdsløsheden er dog faldet de senere år, men var - da "projekt Hejrede Vold" løb af stabelen i 1995 og 96 - på ca. 12\%.

De to sidstnævnte faktorer angår alene feltarbejdet og er de to hensyn, der har haft størst betydning for planlægningen af "Projekt Hejrede Vold", den opgave, som er kærnen i denne artikel. Dette projekt kan kort karakteriseres som en undervisnings- og aktiveringsopgave for et hold på 
11215 bistandsklienter. $1 / 5$ af arbejdstiden var afsat til almindelig basisundervisning (se senere) og indgik ikke i det museale arbejdsforløb, men varetoges af den organisation, "Lollandsprojektet", som museet samarbejdede med om opgaven. I de resterende $4 / 5$ foregik det museumsfaglige arbejde i et kombineret arbejds- og undervisningsforløb (learning by doing). Museet var ansvarlig for det museumsfaglige i denne del af processen.

\section{ET KOMBINERET FORSKNINGS-, MUSEUMS-, UNDERVISNINGS- OG SOCIALT PROJEKT}

Den store arbejdsløshed og det deraf eksisterende behov for arbejdspladser med meningsfyldt arbejde og det ikke sæerlig store beslag, nødudgravninger som ovenfor nævnt lagde på museets arkæologiske kapacitet, gjorde "Projekt Hejrede Vold» til en oplagt opgave. Ved at engagere museet i projektet var der mulighed for at dreje det handicap til succes, som den lave anlægsvirksomhed er, og kompensere for den handlingslammelse, som let kunne blive konsekvensen af den nedskaring af museets arkæologiske driftsmidler, der i 1995 var dekreteret internt på museet. Men det mest tillokkende ved "Projekt Hejrede Vold" var den mulighed, projektet åbnede, for at organisere opgaven på en anderledes måde end den, der er sædvanlig praksis for tilsvarende projekter, og hvor de faldgruber kunne undgåes, som kan gøre sådanne arbejdsforløb til en tvivlsom gevinst set fra museumsfaglig side. Af samme grund fik "Projekt Hejrede Vold" et så heldigt forløb, at det er værd at trakke frem og redegøre for, og det p\& trods af at anvendelse af arbejdsmarkeds- midler, sociale midler o.l. efterhånden er en gammel traver i dansk museumsverden, både i projektformen, og når det foregår integreret $\mathrm{i}$ den faste stab, der varetager det daglige museumsarbejde. Samtidig var den sociale/undervisningsmæessige side af projektet planlagt med så store ambitioner fra den organisations side, som museet samarbejdede med i projektet, at det set fra museets side fremtrådte som en relevant opgave i lokalsamfundet at være med til at løse. Dette ikke mindst som kulturinstitution på Lolland-Falster, en landsdel, hvor behovet var stort for arbejdsopgaver af denne karakter.

Det har en aktualitet at se "Projektet Hejrede Vold" efter i sømmene, at redegøre for det organisatoriske og sætte det ind $i$ en museologisk sammenhreng. Netop sidste år (1999) er det faglige udbytte ved projektet publiceret i international, videnskabelig sammenhæeng ${ }^{4}$, og ved et foredrag i Det Kgl. Nordiske Oldskriftselskab. Samtidig er det formidlingsmateriale lagt ud pà internet, der i samarbejde med Amtscenteret i Maribo er udarbejdet til undervisningsbrug .

\section{Forskningsopgaven og museumsarbejdet $i$ projektet}

Det arkxeologiske udgangspunkt for projektet er levnene af et stort forsvarsværk ved Maribo søerne, en simpel vold og grav med et enkelt jordværk til udkig. Mellem Hejrede Sø og Røgbølle Sø har det dannet en $1,3 \mathrm{~km}$ lang barriere.(se fig). Af denne strækning er ca 350 meter bevaret og fredet. Tre og en halv kilometer vest herfor, mellem Røgbølle Sø og Maribo Søndersø lå en anden valdig jordvold, tilsyneladende opkast fra en moderne vandafledningsgrøft. I den $x$ ldre lokalhistoriske litteratur 


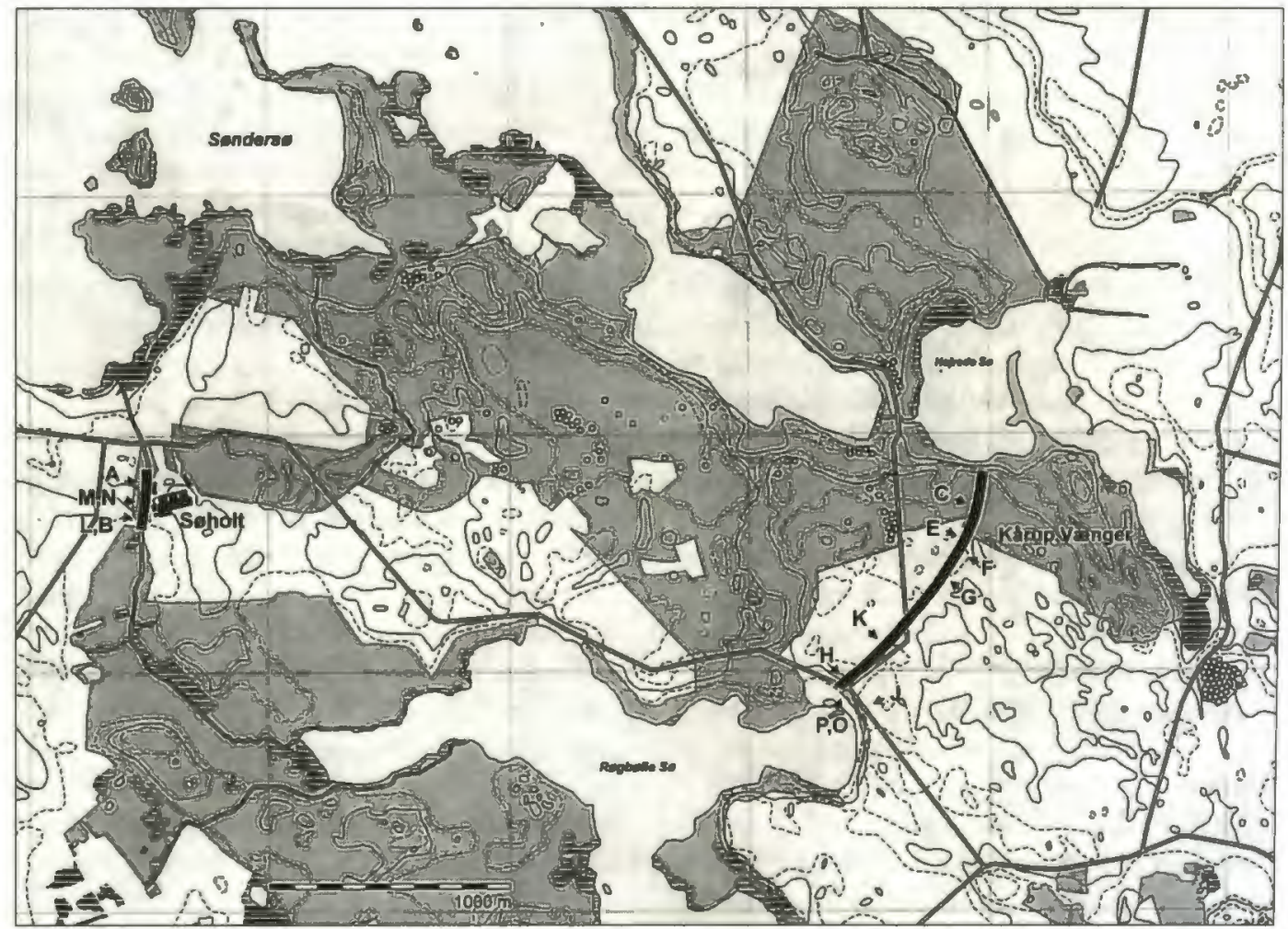

Hejrede Vold, forsvarsvold mellem Mariboswerne fra jernalderen. Udgravingsarbojdet foregik integreret med formidling udstilling, undervisning, idet udgravningsholdet pd 15 deltagere pd een gang havde rollen som museumsgest/medarb jider/elev. Bogstaverne henviser til udgravningsfelterne.

er det foreslået, at også denne jordvold og den tilhørende grøft var en del af det samme militære anlæg som forstnæunte. Denne idé, senest fremsat $i$ en artikel $i$ SKALK ${ }^{6}$, var ét af incitamenterne til projektet. Var der hold i den, ville anlægget i sin form og funktion mere ligne de tilflugtsborge, der er en almindelig type fortidsminde i Østersøegnene, på Øland, Gotland, Bornholm, Falster og de svenske landskaber i øvrigt. Hejrede Vold er blot større end disse med et landområde på 5 kvadratkilometer, skærmet af vold/grav, sø og sump. Samtidig ville Hejrede Volds funktionelle fremtoning være anderledes end den anlagstype, folkevolde, den ofte er kategoriseret sammen med, men som sjzeldent omkranser et landomràde, og snarere har ligget som en barriere i landskabet. Både dette forhold og spørgsmålet om datering var værd at få undersøgt nærmere.

I den lokalhistoriske litteratur formodes forsvarsværket at være anlagt i vikingetid eller tidlig middelalder, den periode som historieskrivere, bl.a. Saxo Grammaticus, 
114 fremstiller som urolig med overfald fra venderne. Men da der hverken var nogen arkæologiske fund fra Hejrede Vold eller fra det tilsvarende voldanlæg på Falster, "Falsters Virke", var denne tidsfæstelse uden konkrete holdepunkter. Med de senere års forskning tegnede Hejrede Vold til snarere at være et militært anlæg fra oldtiden. Alt $i$ alt var der behov for en undersøgelse, hvor man ved et antal udgravningsfelter, placeret hensigtsmæssige steder $\mathrm{i}$ anlægget, kunne fà oplysninger om dette vældige forsvarsværks opbygning, brug og alder. Ved at engagere Stiftsmuseet var der mulighed for at bidrage til den udforskning af simple voldanlæg, som er foregået flere steder i de senere år, især i det vestlige Danmark.

Fredningsmyndighederne gav dispensation fra fredningensdeklarationen til at foretage udgravning i de bevarede dele af anlægget. Det var en anden vigtig forudsætning. Forventningerne til det faglige og museale udbytte blev tilfulde indfriet, efterhånden som projektet skred frem. Hvad de faglige resultater angår, henvises til den anførte litteratur.

\section{Den sociale dimension $i$ "projekt Hejrede Vold" til inspiration for andre EU mål 3- omräder}

Museets samarbejdspartner var "Lollandsprojektet", en selvejende og kommunalt størtet institution, der organiserer og afvikler kurser og arbejdsforløb efter lovbestemmelserne om aktivering af bistandsklienter. Økonomisk baseres denne virksomhed på bevillinger fra EU's regionale fonde; og det var muligt, fordi Lolland på dette tidspunkt ligesom Nordjylland var de to regionale udviklingsområder $\mathrm{i}$ Danmark, såkaldte «EU mål 2 og mål 3 områder", med midler til støtte for henholdsvis erhvervsmæssige og sociale formål. I dag er områderne i EU for mål 2 og 3 udvidet betragteligt. Bare indenfor Storstrøms amt er nu også Falster og Møn defineret som områder, der kan søge EUregionale fonde og f. eks. Bornholm er nu også med. Som inspirationskilde har oplysninger om arbejdsvilkår og organisationsform derfor fået interesse for andre museer udenfor disse to landsdele.

«Lollandsprojektet» var på udkig efter en opgave, der kaldte på et stort spektrum af evner og interesser hos kursisterne. Den skulle være egnet til et hold på som nævnt 15 personer og af 9 måneders varighed. Opgaven måtte ikke være konkurrenceforvridende, og den skulle indholde håndgribelighed. Der var en pædagogisk målsætning med uddannelse, oplevelse, personlig udvikling, kreativitet og hårdt fysisk arbejde. Resultatet af arbejdet skulle have en blivende værdi i lokalsamfundet, gerne noget med turisme. Det var mål, som rakte langt ud over de sædvanlige for de beskæftigelsesprojekter, som normalt afvikles i samarbejde med museer.

\section{Financieringen}

EU mål 3-midlerne var det solide fundament og forudsætningen for, at de mål, som var stillet op, kunne indfries. Det blev til ni måneder i 1995 og en forlængelse på 4 måneder i 1996, hvor projektet afvikledes. Financieringen var på $\mathrm{i}$ alt ca. 1 million. Heri er ikke medregnet lønnen til kursisterne, som de pågxldendes kommuner udbetalte. Hvor stor en del af disse midler der anvendtes til de museumsspecifikke opgaver, giver omtalen i det følgende et indtryk af. 
Vigtige punkter ved organisering af arbejdsopgaverne

Inden projektet gik i gang, var der lagt en plan for forløbet efter et helhedssyn, der både omfattede det faglige og sociale aspekt $\mathrm{i}$ opgaven. Helhed og detaljer var gennemdrøftet mellem de to involverede institutioner. Kompetence og ansvar var på plads. Begge parter vidste, hvad de kunne forvente af hinanden, og hvad de hver især skulle bidrage med. Ved denne planlægning trak jeg på mange års erfaring i museumsverdenen med henvist arbejdskraft. Og desuden på erfaringer som daglig leder af udgravningerne ved det middelalderlige voldsted, Eriksvolde, et beskæftigelsesprojekt som Nationalmuseet i samarbejde med Storstrøms amt for år tilbage iværksatte som led i bekæmpelse af ungdomsarbejdsløshed. Desuden på min erfaring fra deltagelse i udgravninger i Middelhavsområdet, som traditionelt foregår med store arbejdshold, i modsætning til de hjemlige, hvor maskinkraft har afløst arbejdssjakkene.

- Det er vigtigt, at museet ikke har ansvaret for den sociale dimension i sådanne projekter. Dels er der tilstrækkeligt arbejde med det fagarkæologiske, da normeringen af arkæologisk personale $\mathrm{i}$ disse sammenhænge sædvanligvis kun er kneben. Dels kræver dygtigt socialarbejde med så store hold, der her var tale om, et specialuddannet og erfarent personale. En konsekvens heraf var, at de eksterne medarbejdere formelt set var i aktivering på "Lollandsprojektet", og ikke på museet. Konstruktionen udløste således ikke et forøget statstilskud til museet.
- Et kardinalpunkt for et sådant projekts succes er, at begge parter gør sig klart, hvor de har deres professionalisme, og koncentrerer sig om det.

- Samtidig må begge parter have så megen konkret viden om, interesse for og erfaring med samarbejdspartnerens arbejdsområde, at de overlapninger, der nødvendigvis $\mathrm{i}$ det daglige må forekomme mellem socialarbejdet og det museumsfaglige, kan foregå uden problemer. Mine forudsætninger som museets projektansvarlige berørte jeg ovenfor. Lollandsprojektets var den lykkelige kendsgerning, at deres projektansvarlige havde studeret arkæologi i nogle år, og bag sig havde feltarkæologisk erfaring.

- Den instans, der styrer projektets overordnede økonomi, i det konkrete tilfælde Lollandsprojektet, må have forståelse for museets stramme økonomiske situation og for, at museet ikke $\mathrm{i}$ videre omfang kan gå ind i projekter med egne driftsmidler.

Stiftsmuseet ansatte en universitetsuddannet arkæolog i hele projektets forløb som daglig leder af det arkæologiske feltarbejde og med beretningspligt. Det blev til i alt 13 måneders ansættelse-. Museet fik refusion for lønnen af Lollandsprojektet, hvor midlerne regnedes for instruktør-/lærerløn. Tilsvarende indgik i Lollandsprojektets budget alle udgifter til redskaber, skurvogne, kørsel, materialer, film o.s.v. Midler til beretningsfasen, som ikke kunne includeres i Lollandsprojektets budget, skaffedes ved lønrefusion fra Lollandsprojektet for det arbejde, museets formidler udførte i forbindelse med den 
116 efterfølgende etape af projektet, udstillingen. Udgifterne til udstillingen var ligeledes en del af "projekt Hejrede Volds" økonomi, både materialer, udgifter til trykning, kørsel af vandreudstillingen m.v. Derimod var det arbejde uden refusion, som artiklens forfatter udførte som den arkæologisk ansvarlige for udgravningen. Det var en del af museets tilskud til projektet.

- Med så store arbejdshold som det aktuelle, er det vigtigt, at der er instruktører nok, så arkæologerne også får tid til de fagspecifikke sider af opgaven, som kræver stilhed og eftertænksomhed. I det daglige var der afsat gennemsnitligt tre fuldtidsstillinger til at holde projektet $\mathrm{i}$ gang, heraf var den eksterne arkæolog den ene. I en periode, hvor meget opmålingsarbejde skulle fra hånden, blev f. eks. ansat en instruktør med erfaring som landmåler. Opmålingsarbejder tilrettelagdes som praktik i den matematikundervisning, kursisterne deltog i.

- Er normeringen til det arkæologfaglige personale stram, må der skabes luft $\mathrm{i}$ arbejdsskemaet. Ved Hejrede Vold blev der taget højde for det ved at placere den undervisning, som var en del af kursisternes program, på én og samme dag $\mathrm{i}$ ugen (engelsk, dansk, matematik, EDB på 9. og 10. klasse). Denne dag blev der ikke gravet, og arkæologen kunne i fred og ro gøre status over forløbet, have tid for sig selv i marken f. eks. til tolkning af profiler, lægge plan for den kommende uge m.v.

- Det styrker på flere måder et projekt, hvis det $\mathrm{i}$ sit forløb integreres $\mathrm{i}$ og krydses med andre. "Projekt Hejrede Vold" blev på et tidspunkt udvidet med en \$26-udgravning af de stærkt truede og overpløjede dele af anlægget. Midlerne fra Rigsantikvaren kom i lokalsamfundet til at virke som en blåstempling af projektet, ikke mindst hos de politikere, som havde bakket op om den basale bevilling, så interessen og velviljen omkring projektet steg. Rent udgravningsteknisk var det også en gevinst, fordi midlerne fra Rigsantikvaren kunne bruges til maskinkraft; på EU-midlerne var der restriktioner i denne henseende.

- For at fastholde kursisternes interesse $\mathrm{i}$ den hårde udgravningsfase, er det en god idé at planlægge arbejdet ind $\mathrm{i}$ en bredere museal sammenhæng og gøre deltagerne aktive i formidling. I "Projekt Hejrede Vold" annonceredes med omvisninger $\mathrm{i}$ udgravningen for turister, og efter en startfase med instruktørhjælp fra arkæologen optrådte flere af deltagerne som guider. Interessen fra publikum var for kursisterne et incitament $i$ det videre arbejde. Aktiviteten gav samtidig anledning til presseomtale.

- Interessen styrkes ved i projektet at indbygge en glæde ved at gå på opdagelse $f$. eks. ved ekskursioner med det formål at opsøge spændende historiske elementer i kulturlandskabet. Den håndværksmæssige baggrund deltagerne mødte med gjorde f. eks. besøg i en kirke til en oplevelse; betagelsen af tømmerarbejdet på kirkeloftet, af murerarbejdet etc. Økonomien tillod foruden ekskursioner til Trelleborg, udgravningerne på ruinterrænet ved Vordingborg, Nationalmuseet, Rigsarkivet m.v. også en udenlandsrejse til Irland for hele holdet. Det primære mål var at besøge et projekt i 
en anden region indenfor EU, der ligeledes er plaget af arbejdsløshed, og som Lollandsprojektet i forvejen stod i kontakt med, da det var beslægtet med "Projekt Hejrede Vold» og financieret på den samme måde. Samtidig lagdes ekskursioner til fortidsminder og andre historiske levn i det så helt anderledes kulturlandskab end det hjemlige; men det var mødet med det irske beskxeftigelsesprojekt, der gjorde størst indtryk på rejsedeltagerne.

- Drama og rekonstruktion af fortiden ved det fortidsminde, der undersøges, er en anden måde at styrke deltagernes interesse på. Med en vikingekampgruppe fra København som instruktører og optrædende opførtes rekonstrueret jernalderkrig ved Hejrede Vold, dog var kun fodfolk repræsenteret. For kursisterne gav det liv til det fortidsminde, som det kostede dem så megen møje at undersøge. I denne sammenhæeng er det underordnet, at rekonstruktionen ikke er helt så autentisk, som den kunne være. En video, der blev optaget af dette drama, brugtes senere i udstillingssammenhæeng.

\section{- Arbejdsforløb som «Projekt Hejrede} Vold" er, for at opfylde beskxeftigelsesmæssige mål (jf. lovgivningen), nødt til at køre over flere måneder, end det er hensigtsmæessigt for feltarbejdet. I det konkrete tilfælde i 9 måneder, senere forlænget med 4. For at undgå udendørs arbejde i vintermånederne, er det en god idé f. eks. at indlægge en fase med udstilling. Det gav i det konkrete tilfælde samtidig kursisterne den tilfredsstillelse, at opgaven på denne måde blev afsluttet og afleveret. Det var et stolt arbejdshold ved udstillingsåbningen. Samtidig var det et nyttigt, parallelt arbejde til beretningen og med gensidig inspiration mellem disse to processer. Mens udstillingen opbyggedes, blomstrede kursisternes kreativitet. Pludselig foldede andre medarbejdere sig ud end dem, der havde været toneangivende i felten. Der blev opfundet snedige montrer, svejset plancheholdere, tegnet, syet legemsstore jernalderkrigere, bygget modeller over voldanlægget, og vảben blev rekonstrueret. Selv om en udstilling af denne art måske bryder med den stil og det koncept, som museets professionelt fremstillede udstillinger fremviser, lyste entusiasmen i den grad ud af det færdige produkt, at det også for museet var en værdig afslutning på de mange måneders engagement $\mathrm{i}$ et sådant kombinerede forsknings-, socialt- og formidlingsmæessigt projekt.

\section{- og bolden rullede}

Da projektet afslurtedes, var udgravningen og beretningen fra hånden; der var formidlet ved omvisninger $\mathrm{i}$ udgravningen, ved den store udstilling og i vandreudstilling. Men de sidste faser manglede: publikation til den videnskabelige verden og formidling til skoler. Det lykkedes at formulere et projekt for skoleformidlingen i samarbejde med amtscenteret i Maribo, som de østlollandske kommuner greb og financierede indenfor rammerne af det Kulturregionsforsøg, der i 1996 startede i Storstrøms amt. Bevillingen på ca. $115.000 \mathrm{kr}$. muliggjorde ansærtelse af den samme arkseolog, der havde haft den daglige ledelse af udgravningen, af en lærer samt en tegner. Storstrøms EDB-Projekt åbne Samlinger var inde $\mathrm{i}$ billedet $\mathrm{i}$ den 
118 sidste fase, da materialet skulle bearbejdes grafisk m.v. til udlægning på internet". Hånd $\mathrm{i}$ hånd med denne elektroniske formidling, hvis resultat i februar 1999 præsenteredes for offentligheden", indledtes forarbejdet til den forste videnskabelige publikation. Undersøgelsen blev således afrundet med den research af emnet, som begge publikationsformer krævede.

Statens Museumsnævn størtede fasen med videnskabelig formidling med bevilling til deltagelse $\mathrm{i}$ Sachsersymposier $\mathrm{i}$ Mannheim, hvor udgravningsresultaterne blev fremlagt og senere trykt i kongresbererningen ${ }^{10}$, som udkom i april. Formidling til den videnskabelige verden, opfattes ofte i lokalsamfundet som en sofistikeret arbejdsgang, der er det brede museumspublikum uvedkommende. I forbindelse med "Projekt Hejrede Vold" var det imidlertid ikke vanskeligt at argumentere for betydningen af forskning. En forudsærning for midlerne til udgravningen var, at arbejdet havde en varig betydning. For at indfri dette og bringe dette militære anlæg fra jernalderen ind i skolernes historiebøger, er det nødvendigt at gøre det almindelig kendt blandt fagfolk. Ellers forbigåes det, når oversigtsværkerne om Danmarks forhistorie skrives. Arbejdet med Hejrede Vold er nu nået dertil, hvor dette mål er inden for rækkevidde.

\section{KONKLUSIONER}

Projektet er bemærkelsesværdig i forhold til tilsvarende arkæologiske og beskæfrigelsesmæssige udgravninger dels ved den ambitiøse målsætning vedr. den sociale/ undervisningsmæssige dimension $\mathrm{i}$ opgaven, dels ved den professionalisme, hvormed denne del af arbejde blev grebet an, dels ved den integration mellem udgravning og formidling, som blev etableret, bl.a. af pædagogiske grunde. Det er også bemærkelsesværdigt ved, at der var tilstrækkelige økonomiske midler til rådighed, som - sammen med den entusiasme, medarbejderne fra de to involverede institutioner udviste (Stiftsmuseet og Lollandsprojektet) - var skyld $i$, at også de fagarkæologiske målsætninger blev indfriet.

I museumsverdnen er opgaven imidlertid atypisk. Normalt sættes al kapaciteten på et arkæologisk arbejdende lokalmuseum ind på nødudgravninger. De specielle, samfundsberingede forhold på Lolland, som umiddelbart er negativ for museets udfoldelsesmuligheder, blev kortlagt og udnyttet, og det lykkedes at dreje situationen til succes. Logistikken bag "Projekt Hejrede Vold", er imidlertid ikke særlig kendt i dansk museumsverden. Der har været travlt med at formidle de faglige resultater, så det organisatoriske er kommet i anden række. Samtidig har atypiske aktiviteter en tilbøjlighed til at blive overset, når et generelt billede af museumsverdnen tegnes $\mathrm{i}$ de forskellige sammenhænge. Skal et billede afspejle virkeligheden sandfærdigt, må imidlertid både det generelle og det afvigende med. Selv i skildringer af det regionale museumsvæsen, hvor stoffet er begrænset, og detaljer derfor fremtræder, gælder den samme tendens. Det var f. eks. tilfældet i den redeg $\emptyset$ relse for museumsdrift i Storstrøms amt, der blev udarbejdet som redskab for politikerne til museumsplanlægning $\mathrm{i}$ regionen $i$ forbindelse med Kulturregionsforsøget", en fire årig periode, hvor ansvaret for museumsdrift på forsøgsbasis var flyttet helt væk fra statsligt regi til alene at påhvile det amtslige og kommunale nive- 
au. I denne redegørelse blev de arkæologiske museers aktivitet målt i en graf efter feltarbejde. Hver sag talte 1 point, hvad enten det var en besigtigelse af en dags varighed, en lille udgravning på en uges tid eller noget bekosteligere og mere langvarigt. "Projekt Hejrede Vold"s tretten måneders arbejde for en bevilling på 1 million kroner fik kun det samme, ene point. Rapporten lod derfor hverken skinne igennem, hvor differentieret museumslandskabet er, eller at museernes tilpasningsevne til den specifikke samfundssituation i hvert deres virkeområde er stor. Virkeligheden var, at der kom en afledt effekt af Projekt Hejrede Vold. Projekter betød et synligt løft for Stiftsmuseets samlede aktivitet i de to år, det foregik, og det gav institutionen en anden tilknytning til dets virkeområde end den traditionelle for et lokalmuseum. Rent faktisk var LollandFalsters Stiftsmuseum - som kulturinstitution $\mathrm{i}$ en landsdel med svigtende anlægsarbejde og derfor få nødudgravninger - gået egne veje og havde taget udgangspunkt i en anden samfundsbetinget, men lige så legal situation for lødigt arkæologisk arbejde, som trussel fra anlægsarbejde udgør.

Oplæg på Museologisk Nerværks møde i Brede, 24/11-99, revideret 14/5-2000.

\section{NOTER}

1. Bl.a. Walter Hochreiters bog, Vom Musentempel zum Lernort, zur Sozialgeschichte deutscher Museen 1800-1914. Darmstadt 1994. Om tiden fra $1914 \mathrm{og}$ frem se bl.a. : G. Kossack:

Prehistoric archaeology in Germany, its history and current situation. Noruegian archaeological
Review 25, 1992, s 73-109

- H. Härke: All quiet on the Western Front?

Paradigms, methods and approaches in West German archaeology, i: I. Hodder (red.), Archaeological theory in Europe, s $187-222$. London og New York 1991.

- E. Gringmuth-Dallmer: Archaeology in the former German Democratic Republic since 1989, Antiquity 67 (1993), s 135-142.

- R. Schild: Polish archaeology in transition, Antiquity 67 (1993), s 146-150.

2. J.J.A. Worsaae: Danmarks Oldtid oplyst ved Oldsager og Gravhöie. Udg. Selskabet for Trykkefrihedens rette Brug. Köbenhavn 1843, s 116.

3. Problemstillingen er behandlet i Lolland-Falsters Historiske Samfunds Årbog 1998, s 61 ff, i arriklen, Løkkegaard Poulsen, K.: Vikinger og vendere på Lolland-Falster, afsnittet "arkæologi og politik".

4. Lokkegaard Poulsen, K.: «Hejrede Wall», eine Wehranlage auf Lolland, Dänemark. Die Ausgrabungen 1995, 1996 und die Perspektiven. I: Völker an Nord-und Ostsee und die Franken, Kolloquien zur Vor-und Frühgeschichte, Bd. 3. Mannheimer Geschichtsblätter, Neue Folge, Beiheft 2, Bonn 1999, s 107 ff., og samme: Hejrede Vold - et overset anlæg i skandinavisk jernalderforskning. I: Arksologisk forum, $\mathrm{nr} 1$, 1999, s 9 ff. Tidligere er publiceret:

Christensen, K.: Hejrede og Søholt - et forsvarsanlæg. I: Under Storstroms Himmel, kulturlandskabet i Storstroms Amt. Museumsrådet 1996, s 17 ff. Løkkegaard Poulsen, K. og Christensen, K.: Fortids magt og ære - udgravningen af voldanlægget Hejrede/Søholt. I: Lolland-Falsters Historiske Samfunds Arbog 1995, s 109 ff.

5. http://www.aabne-samlinger.dk/hejrede

6. Thorsen, S. Lollands virker. SKALK, nr. 2, 1993 , s $3 \mathrm{ff}$.

7. Cand. mag. Kirsten Christensen var den daglige leder af den arkæologiske udgravning. Erik 
120 Mandrup-Poulsen var den projektansvarlige fra Lollandsprojektet, mens denne artikels forfatter var projektansvarlig for den arkæologiske udgravning (Lolland-Falsters Stiftsmuseum).

8. Projektleder for PAS, Lars K. Christensen "oversatte" materialet til homepages i samarbejde med arkæolog Kirsten Christensen og fra

Amtscenteret for undervisningsmidler i Maribo, lærer Annemette Hansen.

9. se home-page adressen i note 5.

10. se litteraturhenvisningen i note 4 .

Sachsersymposier er et forum for forskere fra Nord- og Mellemeuropa, der mødes vedr. emner indenfor jernalder.

11. Rapportens titel er: Museumsudredning vedr. Storstroms Amt. Museer, arkiver, besogscentre Modeller for en fremtidig udvikling og opgavefordeling. April 1997.

\section{SUMMARY}

Education, experience and employment

"Hejrede Wall", a museums project matching the requirements of sociery.

The paper focuses the interaction between the activity of museums and the situation and stage of development of the surrounding society. The interaction mentioned is a suitable parameter in studying and describing the development of museums in the past. As an example the paper sketches the differing development in Germany and Denmark from the 1830 s to 1989 in 1) the use of museum objects as symbols of the nation and as a means to national identification for the populations in the European countries, and 2) in the way historic and prehistoric topics are synthesised. But the same parameter is an unavoidable tool in the forward planning of museums. The museum mirrors its surrounding society and enlightens the population about the conditions of human life and thus makes people better suited to navigating their proper own times. The media available to the museums are multifarious: exhibitions, slideshow, publications, performance of historic theatre/drama, workgroups etc.

The Hejrede Wall Project, the main topic of this paper, is an example of a well integrated course, where research, archaeological field-work, guiding for tourists at the site, the building of an exhibition and the distribution of a travelling exhibition, drama, employment, and education at compulsoryschool level go hand in hand. The Lolland-Falsters Stiftsmuseum collaborated with 15 unemployed men and women. Using an integrated model they became visitors to the museum, member of the staff and students at the same time.

At the centre of this project were the relics of a huge military prehistoric system, an earthwork consisting of a bank, a moat and a hill serving as an observation post. The whole rampart surrounded an area of 5 squarkilometres of land berween the Maribo Lakes in the centre of Lolland. The project was succesful. Trenches were dug through the wellpreserved parts of the forrification and in the fields, the parts of the structure which had been ploughed over were found and mapped. The Hejrede Wall was revealed as a fortification from the Iron Age, about $550 \mathrm{AD}$. The starting point was established for further research inside the rampart to reveal the function of the rampart. At the same time the 15 participants experienced a wide variety of course work, and education, in accordance with the concept of Learning by doing.

Thus the Hejrede Wall Project was successful both from the point of view of the museum and of the participants.

\section{LITTERATUR}

Christensen, Kirsten: Hejrede og Søholt - et forsvarsanlæg. I: Under Storstroms himmel, kulturlandskabet $i$ Storstroms amt, 1996, s $17 \mathrm{ff}$. 
Engström, Johan: Fornborgarna och samhällsutvecklingen under mellersta järnåldern. I: Fabech/Ringtved (red.): Samfundsorganisation og Regional Variation. Norden i romersk jernalder og folkevandringstid. Beretning fra nordiske jernaldersymposium 1, 1989. Jysk Arkæologisk Selskabs Skrifter 27 (1991).

Gringmuth-Dallmer, E.: Archaeology in the former German Democratic Republic since 1989, Antiquity 67 (1993), s 135-142.

Hochreiter, Walter: Vom Musentempel zum Lernort, zur Sozialgeschichte deutscher Museen 1800-1914. Darmstadt 1994.

Härke, H. All quiet on the Western Front? Paradigms, methods and approaches in West German archaeology. I: Hodder, I. (red.) Archaeological theory in Europe, s 187-222, London og New York 1991.

Kossack: Prehistoric archaeology in Germany, its history and current situation. NAR 25, 1992, s 73-109.

Løkkegaard Poulsen, Karen: Arkæologi på LollandFalster - i tre og et halvt århundrede. LollandFalsters Stiftsmuseums Arsskrift 1990, s 37-64.

Løkkegaard Poulsen, Karen: Vikinger og vendere på Lolland-Falster, afsnittet Arkæologi og politik, Lolland-Falsters Historiske Samfunds Arbog 1998, s $61 \mathrm{ff}$.

Løkkegaard Poulsen, Karen; "Hejrede Wall”, eine Wehranlage auf Lolland, Dänemark. Die Ausgrabaungen 1995, 1996 und die Perspektiven. I: Völker an Nord-und Ostsee und die Franken. Kolloquien zur Vor- und Frühgeschichte. Bd. 3, Mannheimer Geschichtsblätter, Neue Folge, Beiheft 2, Bonn 1999, s 107 ff.

Løkkegaard Poulsen, K.: Hejrede Vold - et overset anlæg i skandinavisk jernalderforskning. Arkeologisk forum, nr. 1, s 109 ff. Foreningen af fagarkæologer, Københavns Universitet, 1999.

Paludan-Müller, Carsten: Museet i riden - erindringsrum og verdensspejl. I: Museerne ved ărtu- sindskiftet, red. Lauenborg, M. og Pentz, P.,
Worsaae, J.J.A.: Danmarks Oldtid oplyst ved

Oldsager og Gravhöie. Udg. Selskabet for

Trykkefrihedens rette Brug. Kjöbenhavn 1843.

Karen Lokkegaard Poulsen, mag. art. i forhistorisk arkeologi. Hojskolelerer, konsulent vedr. kulturlandskab pa Storstroms amis og Ribe amis landskabsforvaltninger. 1979-1999 museumsinspektor ved Lolland-Falsters Stifismuseum og ansvarlig for dets arkeologiske arbejdsomräde.

Adr: Bekkasinvej 21, DK 4930 Maribo, Danmark e-post: karen.loekkegaard@image.dk 